Education and Empioyment

Population and Human Resources

Department

The World Bank

May 1991

WPS 683

\title{
Vocational Schooling, Occupational Matching, and Labor Market Earnings in Israel 0 $\xi$
}

\section{Shoshana Neuman}

and

Adrian Ziderman"

Case studies in the past two decades have strongly argued against vocational schooling on cost-benefit grounds but some recent studies have reached different conclusions. 
WORKING PAPERS

Eduontion and Employment

WPS 683

This paper - a product of the Education and Employment Division, ᄀ Population and Human Resources Department - is part of a larger effort in PRE to develop policios to improve private and public skills training in developing countries. Copies are available free from the World Bank, $1818 \mathrm{H} \mathrm{Street} \mathrm{NW,}$ Washington, DC20433. Please contact Cynthia Cristobal, room S6-214, extension 33640 (27 pages, with tables).

Neuman and Ziderman conducted a comparative analysis of the earnings of workers in Israel who had last attended vocational schools and those who had last attended academic secondary schools before entering the if br force. Their findings suggest that Isfael may proxide an example of an educational system in which vocational schooling is economically effective.

V̈ocational schooling in Israel has proven more cost-effective than general academic training. In particular, vocational school attenders who later worked in occupations related to their course of study eamed more. Their wages were up to 10 percent more a month than their peer who studied at academic second. ary schools and those who attended vocational schools but found employment in occupations not related to the subjects they studied.

The results of the research in Israel reinforce similar findings in recent research on vocational schooling in the United States.

A caveat is necessary to temper the generally positive findings concerning vocational school. ing in Israel. While vocational school is costeffective cherpared with other forms of secondary schooling, it does not compare favorably with other forms of training for skilled trades, such as apprenticeships and factory-based vocational schools.

Another factor is the national consensus in Israel favoring education designed to equip young people for the social and cultural role of integrating the country's heterogenous, largely immigrant population. This consensus acts as a major constraint on the development of training altematives that are the nom for youth in other countries.

The desire to meet manpower needs for development plays an important role in explaining the growth of vocational schooling in Israel. A predominant factor, however, is the effectiveness of vocational schools in integratinz youth from North Africa and elsewhere in the Middle East into the mainstream of the nation's society. Many of these immigrant younigsters have low academic ability and relatively low socioeconomic status.

'The PRE Working Paper Series disseminates the findings of work under way in the Bank's Policy, Rescarch, and Extemal Affairs Complex. An objective of the series is to get these findings out quickly, even if presentalions are less than fully polished. The findings, interpretations, and conclusions in these papers do not necessurily represent official Bank policy. 


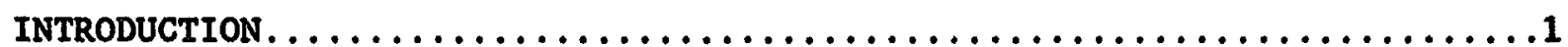

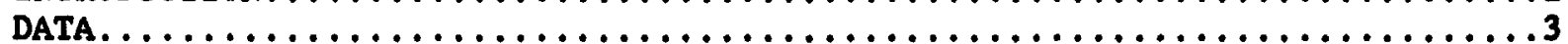

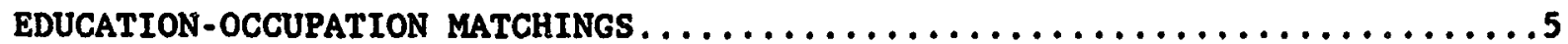

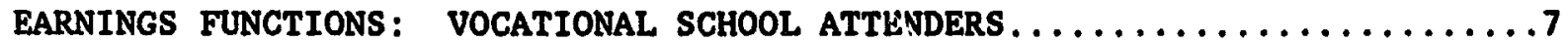

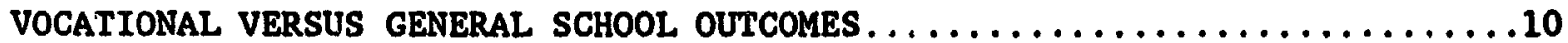

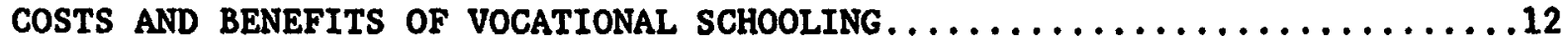

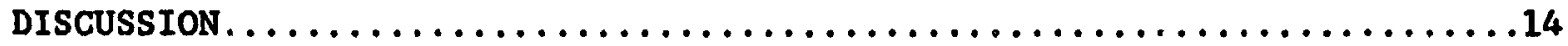

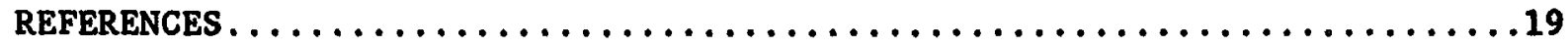

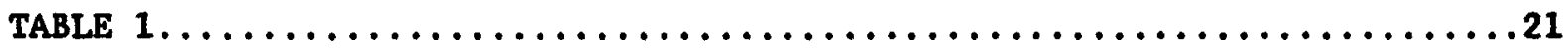

Numbers and Average Monthly Earnings of Matched and Non-Matched

Workers by Subject of Study: Full Time Male Salaried Workers, Attenders of Vocational Schools - Israeli Census, 1983

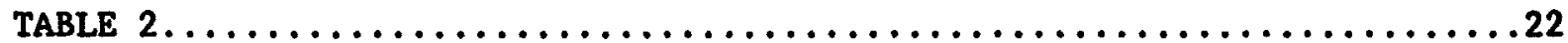

Regressions of Monthly Earnings (in) Full Time, Male, Salaried

Workers, Attenders of Vocational Schools - Israeli Census, 1983

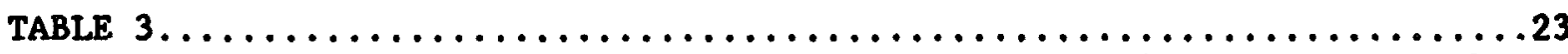

Regressions of Montly Earnings (In) Full Time, Male, Salaried Workers

General and Vocational Schools Attenders - Israeli Census, 1983

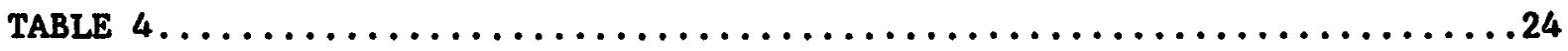

Incremental Net Present Value of Vocational Schooling over Academic Secondary Schooling (Israeli Shekel, per Student)

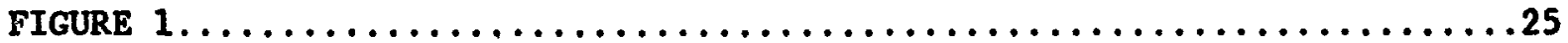

Number of Students in Secondary Schools

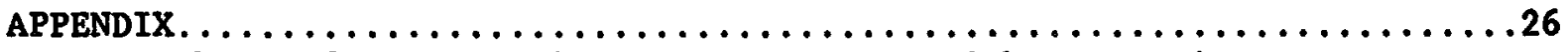

Matching of Vocational Education Course with Occupation

* This paper supercedes "Vocational Secondary Schooling in Israel: A Study of Labor Market Outcomes" (Working Papers Serles No. 142, January 1989). 


\section{Vocational Schooling, Occupational Matching and Labor Market Raroings In Iarael}

\section{Introduction}

The accumulating evidence from over two decades of a growing international case study IIterature, relating to both Western and Third World countrles, has argued strongly against vocational schooling on cost-benefit grounds. This literature, comparing labor market outcomes of vocational with general academic schooling, mainly at the secondary level, has been extensively reviewed by Zymelman (1976), Psacharopoulos (1987) and Tilak (1988); it has been augmented recently by two World Bank studies of vocational education, for Peru (Moock and Bellew, 1988) and for the Ivory Coast (Grootaert, 1988), both of which reach similar negative results with regard to vocational schools.

However, some recent studies for the United States have reached very different conclusions. Focussed more closely than earlier studies on the type of jobs held by vocational school completers (and its relation to vocational courses studied) ${ }^{1}$ as well as on more relevant measures of vocational education, 2 this "new wave" of research reaches far more positive conclusions with regard to vocational schooling. In particular, it concludes that vocational education gives a labor market advantage, whether in terms of labor force participation, earnings or unemployment, to those high school completers who work in jobs related to the vocational courses followed at school; vocational completers working uritside their training specialty fare no better

1 Important recent studies include those by Daymont and Rumberger (1982), and Campbell, et. al. (1986 and 1987).

2 The pioneering work of Meyer is important here. See Meyer (1981); also National Assessinent of Vocational Education 1989. 
than workers who hac pursued general academic tracks. This "new wave" Iiterature on vocational schooling in tl.e United States is reviewed by Bishop (1989). So far, however, these new approaches do not seen to have been utilized in Third World countries and the general negative conclusions of the "vocational schnoling fallacy" 1iterature (dating from Foster, 1965) remain current and largely unchallenged.

A recent paper by the present authors (Neuman and Ziderman, 1989), based upon a comparative analysis of the earnings of workers who had attended vocational or academic secondary schools in Israel, suggested that Israel may provide an example amongst non-rich countries of an educational system where vocational (as opposed to academic) schooling does seem to be economically effective. However, the earlier paper (as is common with the Third World literature as a whole) lacked any discussion of the content of these vocational courses of study and its effect on labor market outcomes. Yet a central objective of vocational schooling (though not necessarily the sole or even major one) is that of providing specific marketable skills to the labor force. The present paper poses, for the Israeli case, the question: do vocational school attenders take up employment in occupations that utilize the vocational skills learned at school, and if so, with what effect on labor market earnings? How do these earnings compere with those of individuals that studied at academic schools? The paper examines the labor market outcomes of vocational secondary education in Israel in terms of the relation of subject studied to occupation entered. The results reported are positive for vocational schooling and provide strong reinforcement of recent, broadly similar studies for the United States.

Israel seems to provide an appropriate framework for studying these issues, given the central role accorded to secondary vocational schools within 
its educational system. Today, over fifty per cent of secondary school p, 1 s are enrolled in vocational tracks. The vocational school sector is not nnly sizeable in terms of enrollments ind number of schools but growing relative to acadeialc schools (Chart 1); in this, too, Israel departs from international trends which have shown a secular shift away from vocational schooling in recent decades (Benavot, 1983).

Vocational schooling, now under the aegis of the Ministry of Education, constitutes the dominant form of training for the skilled trades in Israel (over 80 percent of skilled workers are trained in these schools); for an amalgam of historical, social and cultural reasons, enterprise-based forms of training for youth, such as the traditional apprenticeship, have not developed extensively in Israel. 3 While the Ministry of Education is responsible for curriculum, terminal examinations, teacher training and school inspection, very few schools are formally Government schools. Most: vocational schools are run by public voluntary organizations (the largest is OAT), a few by local municipalitios; all are highly subsidized from Ministry of Education budgets.

Date

As in the earlier paper, the present study draws upon individual data records from the 1983 Census of Population and Housing 20 percent subsample. Information on level and type of terminal schooling was collected, rendering it possible to identify two broad groups of individuals that are the focus of this paper: those who terminated education at a vocational secondary

3 These Issues are discussed more fully In Iram and Ballcki (1980) and Ziderman (1989A). 
and at an academin secondary school, respectively. 4 For secondary school completers that went i to post-secondary education, it was not possible to 1drutify sype of secondary school attended; they are not included in the present analysis. In addition, the Census questionnaire was unusual in addressing a specific question to those individuals whose formal education terminated at the agricultural or vocational secondary school, concerning the major vocational subject of study. This information was used in the present study to probe two central issues zelating to vocational schooling: to what extent are former vocational school attenders employed in occupations related to the main subject area studied at school? Are there significant differences in the earnings of those employed in jobs related to subject studied at school and those not working in subject-related occupations?

This paper relates only to the sub-set of individuals aged 25-49 at the time of the Census. The upper age limit was set in order to exclude Individuals who had attended secondary school before 1948, the year of statehood; the lower, to allow at least three years possible labor market experience, following three-year compulsory military servicis at age 18 . Since our concern is with the Israeli education system, we excluded (on the basis of information on age and year of migration) the large number of immigrants who had attended high sct.ool abroad. Finally, only male Jewish full-time workers (a worker is considered "full-time" if he worked at leest 35 hours in the week prior to the Sensus) are Included. In all, the sample comprised some 14,000

4 In fact, Individuals that had concluded other forms of vocational training for youth, notably the formal apprenticeship and industrial schools, were also included sithin the category of vocational school completers; also included were those that attended agricultural secondary schools. However, these groups constitutis a small, and declining, proportion of vocationally educated students. 
Individuals, nearly 10,000 former vocational school attenders and some 4,000 Individuals who had attended a general secondary school.

\section{Education-eccupation Yatchings}

For each vocational school attender, we compar sd subject studied with current job held (using two-digit occupational codes) to see if vocational education recelved was related to occupetion. Two alternative matching procedures were employed, "direct" matchings and "wider" natchings. For direct matchings, a worker is defined as matched if he works in an occupation directly related to the subject studied; for example, the subject "Electricity" and the occupational category "Electricians/Electronic Fitters" constitute a direct match. Wider matchings include closely related occupations, In addition. In the latter case, we take account of the dynamics of career development: thus an individual who had studied Electricity might go on to become a Technical Salesman or open his own electrical business as a Working Proprietor in the Retail Trades. While admittedly judgmental, it is not thought that the procedures adopted would occasion any great dissent. $s$

5 Detalls of the educational - occupational equivalences used in the matchings procedure is provided in the Appendix. 
Table 1 shows the proportion of matched workers, by field of study, according to direct and wider matching regimes. 6 Overe 11,37 percent of vocational school attenders were employed in occupations related to the course of study pursued (47 percent on the basis of the wider matchings). Leaving aside the categories Sewing \& Fashion, and Hotel Management, where the number of observations are small, the proportion of matched workers does not differ markedly across subject of study categories (with the exception of Agriculture). Relative frequencies range from 38 to 51 percent for direct mat hings and between 45 and 60 percent for wider matchings; ranking by subject differs somewhat for the two matching processes. 7

6 The relative importance of courses of study in agricultural and for blue collar occupations (the first five listed in Table 1) are reflective of the courses typically taken by male attenders at vocational schools (who constitute our sample) rather than the overall spread of vocational courses offered. Females, on the other hand, are dominant in courses of study for white collar occupations. This is shown in the overall proportions of vocational school attenders who had taken courses of study leading to the following groups of occupations (Source: Central Buregu of Statistics, 1988):

Kale (8) Female (8)

$\begin{array}{lrr}\text { Agriculture } & 8.5 & 6.3 \\ \text { Blue collar } & 68.9 & 2.1 \\ \text { White collar } & 5.5 & 70.2 \\ \text { Not known } & 17.0 & 20.3\end{array}$

Thus in focussing only on males (as is typical in studies of this type because of the rather different nature of the relevant earnings function for females) the study essentially addresses itself to courses of study relevant to blue collar occupations.

7 There is also considerable stability of the matched properition, by age. For the five-year age groups between ages 25-49, the percentage of matchings were:

\section{5-29 30-34 35-39 40-45 45-49 A11 Age Groups}

Direct Matchings Wider Matchings

$\begin{array}{lll}38.2 & 39.5 & 36.6 \\ 44.4 & 48.9 & 47.5\end{array}$

$\begin{array}{ll}33.6 & 33.0 \\ 45.0 & 48.4\end{array}$

48.4
37.4 46.7 
The table 31 so reports average monthly earnings for matched and nonmatched workers, by subject. Average earnings of matched workers exceed those of non-natched workers for most subject of study categories. However, no weight should be given to the size of the earnings differential in particular cases since the comparative earnings figures are "gross" ones, with no control made for other factors that may differentially influence earnings; the regression analysis that follows presents "net" results.

\section{Earnings Functions: Yocational school Attenders}

Earnings functions are estimated for the sub-sample of 9,788 individuals who had attended vocational secondary school. The objective of the regression analysis is to examire whether there are significant differences between vocational school attenders that work in field-of-study related occupations and those who do not, holding constant other varlables that may affect earnings.

The specification of the earnings functions is of the traditional Mincer type. The $\log$ of monthly earnings is run against a series of human capital variables, including years of schooling, labor force experience, type of school certification obcained, and a dummy variable (VOC.M) relating to vocational school attenders that were employed in matched occupations, 1.e. occupations related to the vocational coursa of study taken at school.

The main focus of the regressions is the coefficient on the VOC.M variable, holding constant the other explanatory variables relating to other dimensions of education received, to various personal background characteristics, and to aspects of labor market involvement. A positive, and significant, coefficient on the VOC.M variable would indicate that attenders of vocational secondary schools that were employed in occupations related to 
courst of study pursued, earned more, on average, than their counterparts who did not work in matched occupations.

The full set of varlables employed in the regressions are as

follows:

Schooling variables:

YRS.SCH: Years of schooling (ranging from 8 to 12 years)

A dummy varlable VOC.M representing matched vocational school attenders, with non-matched in the constant term.

Subject of study, represented by a series of dumny variables (with Agriculture as the reference group): ELECTRIC (Electricity), ELECTRON (Electronics), METAL (Metal work), AUTO (Automechanics), CLERIC (Clerical and book-keeping), SEW (Sewing $s:$ fashion) and HOTEL (Hotc management). Occupation tummies are not included, because of a high correlation between yocational eubjoct studiad and occupation.

A series of dummy variables, P.CERT, S.CERT and BAG, relating to the highest level of school certification attained -- completed primary or intermediate level, completed secondary schooling, and gained Begrut (matriculation), respectively. The category "no certificate obtained" enters the constant term.

Personal background variable:

ETHNIC: a dummy Indicating ethnic origin (Oriental-1, Western-0).

Work related variables:

EXP: $\quad$ years of work experience (defined as Age-SCH-6)

WEEKS: $\log$ of number of weeks worked in the past year

HOURS: $\log$ of hours worked in the past week 8

A serles of dummy variables relating to sector in which employed: Industry (IND), Electricity (ELECT), Commerce (COMM), FInance (FIN), Transport (TRANS), Public services (PUB), Private services (PRIV), Cor.: :ruction (CONST), with Agriculture in the constant term.

8 The reason for taking the natural logarithm of the weeks and hours varlables is that they are highly skewed to the left (most workers working 45 hours a week and 52 weeks a year). By taking the $\log$, the distribution becomes more symetric. 
Results are presented in Table 2, on the basis of cirect and wider matchirugs, respectively. Before considering the voC.M varlable, we review some of the ocher central results. Whersas the experience terms yield expected resilts (earnings are positively related to years of experience but decline for additional higher years of experlence), the lack of significance on the years of schooling term is to be explained in part by the introduction of the certification terms. However, the positive coefficient on the interaction term, EXP*YRS.SCH (which is not in the traditional Mincer specification) 9 shows the presence of increasing returns to schooling as experience advances (and vice versa).

of more central importance, however, are the coefficients o: the VOC.M term. The coefficients shov that matched workers do achieve higher earnings than their non-matched counterparts; ${ }^{10}$ it is also seen that subject of study exerts a differential effect on earnings. 11 how do the earnings of

9 For a justification for including this interaction term, see Dougherty and Jimencz, 1987.

10 The large VOC.M coefficient in the wider matchings regression (compared to that in the direct matchings) might cccasion surprise. However, the Table 2 regressions do not include controls for occupation; many individuals that are matched under the wider matchings definitions are managers, who tend to coinmand relatively high salaries. Rerunning Table 2 regressions but substituting occupational dummies for the subject-of-study dumies give the following results for the VOC.M coefficient: direct matchings $0.094(7.26)$, wider matchings $0.097(7.96)$.

11 We reran the regressions reported in the previous footnote, for each subject course for which there were sufficient observations. The voc.li coefficients were found to be positive and significant for all of the regressions (except for Agriculture), thus confirming overall that the differential earnings effect is present for the course of study sub-samples. For the direct matchings regressions, the VOC.M coefficients were as follows (the $t$ statistic is shown in parentheses): Electricity 0.109 (2.71), Electronics 0.140 (2.11), Metalwork 0.073 (3.59), Automechanics 0.095 (3.07) and Clerical 1.068 (3.34). Results for the wider matchings are: Electricity 1.09 (2.94), Electronics 0.099 (1.67), Metalwork 0.076 (4.00), Automechanics 0.099 (3.34), and Cierical $0.673(3.28)$. 
each sub-group of vocationally educated individuals compare with those who go through the academic secondary school stream? We probe these issues in the next section.

\section{Vocat lonal Versus General Sehool outcomes}

We turn to the broader sample of former secondary school attenders, comprising those from both vocational and academic secondary school backgrounds. Two dummy variables, relating to type of secondary school attended, are now defined: VOC.M $(-1$, if the worker is a vocational school attender working in a matched occupation, and -0 if otherwise), and VOC.U ( -1 if he is an unmatched vocational school attender, and -0 if otherwise). The reference group is thus workers who had attended general academic secondary schooling. The regression model specification is otherwise parallel to those reported in Table 2, except that a set of occupational dummies replace the subject-cf-study dummies (the Census did not collect information on the latter for academic secondary school attenders). The occupational dummy variables are: Scientific and academic (ACAD), Other professional and technical (TECH), Administrators and Managers (MANAG), Sales (SALES), Services (SERV), Skilled (SKILL) and Unskilled (UNSKILL), with agricultural workers entering the constant term.

The reported coefficients on the VOC.M and VOC.U variables in the regressions in Table 3 are significantly positive and nonsignificant, respectively. The implication of these results is clear. They indicate that while there is no difference in earnings between academic school attenders and those vocational school attenders that work in occupations unrelated to vocational courses studied at school, the earnings of workers employed in 
matched occupations exceed those of workers who attended academic schools (by over 8 percent in the regression relating to wider matchings and by 9.6 percent for direct matchings). 12

The overall regression results in Table 3 lead to an important refinement of the conclusions presented in our earlier paper. We now see that type of school attended, whether vocational or academic secondary, does have an impact on labor market income. It is only when vocational school attenders are employed in jobs unrelated to courses of study pursued at school, that earnings are broadly similar to those of workers who studied at academic secondary schools. For those vocational school attenders who work in studyrelated occupations, average earnings are significantly higher than those of workers who studied at academic secondary schools. 13

12 The actual percentage effect of the voc.M dummy variable on earnings is somewhat higher than the dummy variable coefficlent multiplied by 100 (see Halvorsen and Palmquist, 1980).

13 An anonymous referee has argued that the higher earnings found in training-related occupations may really be just an effect of placement in a high-wage occupation -. whether or not one was specifically trained for it in school. This question has been explored by Hotchkiss (1989); using U.S. data, Hotchkiss finds that adding dumny variables representing occupations nullifies the apparent effect of other dummy variables representing whether a person is in a training-related job. This result is different from those reported in Table 3, where the job-match dumies do remain significant despite the presence of occupation dummies. Two main differences between our work and that of Hotchkiss may account for the differing results. Firstly, our matching procedure is far more detalled than that of Hotchkiss who distingulshes only between two areas of vocational study -. clerical, and trade and Industry -. while we have elght. Thus, for example, a worker who studied electricity but worked as a plumber would be considered matched in the Hotchkiss analysis, but not in ours. Secondly, Hotchkiss considers wages in the first job within two years after high school completion, while our analysis relates to the whole iffe cycle -. In our view the more appropriate focus. 
Costs and Benefits of Vocational Schooling

The regression analyses show that, given the higher earnings accruing to vocational school attenders working in matched occupations (1.e. occupations related to course of study), overall, terminal vocational secondary education yields higher monetary benefits than general academic education. However, the question of the efficacy of vocational schooling is one that relates not just to the relative benefits of vocational and academic schooling, but rather to benefits in relation to respective costs.

While in the comparative international context vocational schooling costs generally exceed the costs of academic schooling, 14 no sound data are available on the relative costs of vocational and general secondary schooling In Israel. However, official estimates of national expenditure on sacondary education are available by type of schooling; 15 from these we may derive rough estimates of relative costs in terms of national expenditures per pupil on vocational and academic secondary schools, respectively. For the financial year 1982/83, which most closely relates to the year of the Census, per pupil vocational and academic schooling costs respectively were 61107 and 33667 Israell Shekel: this gives a ratio of per pupll vocational to academic schooling costs of 1.815 (1.e. vocational schools were over 80 percent more expensive per student than academic schools). 16

14 See Tsang (1989) for a comprehensive review of the evidence.

15 See Central Bureau of Statistics (recent years).

16 Detalls of these cost estimates can be obtained from the authors on request. The cost ratio of 1.815 represents very much higher relative costs for vocational schools than were given in an earlier paper by the authors (Neuman and Z1derman 1989); In that paper the authors overestimated the absolute level of unit costs, and understated the relative vocational academic school unit cost rat1o; we are thankful to Shmuel Amir of the Hebrew University, Jerusalem for this correction. 
Are these higher vocational school unit costs sufficiently sizable to offset the earnings benefits of vocational education (as indicated by those working in matched occupations)? In order to test this, we compared benefits and costs in terms of an investment appraisal; we subjected our overall results to a series of sensitivity tests, by experimenting with alternative values of the parameters in the following equation:

$$
\underset{t-1}{N P V}=\sum^{n}\left[m \vee Y_{A t}(1+g)^{t}-c C_{A t}\right](1+1)^{-t}
$$

where

$X_{A}$ measures average income of academic school completers, in year $t$

$v$ is the proportional earnings advantage of vocational school completers working in matched occupations

m is the proportion of vocational school completers employed in matched occupations

8 secular growth of real incomes

c relates to excess vocational schooling costs over academic school costs and is measured by the ratio $\left(C_{V}-C_{A}\right) / C_{A}$, where $C_{V}$ and $C_{A}$ measure annual costs per student in vocational and academic schools, respectively.

1 is the discount rate, and

n is the time horizon of the appraisal.

Results are presented in Table 4, assuming a 35 year post-schooling time horizon. Our central findings, with positive NPVs, are shown in the boxes in the table. For direct matchings these relate to $v=0.096$ and m $=0.37$ (based on the matched percentages given In Table 1), and for wider matchings to $v=0.081$ and $w=0.47$. In both cases $c=0.815, g=0.02^{17}$ and

17 The historical trend in real wage increases since the early 1970 s has been higher, at close to 3 percent. 
1 - 0.08; three years of secondary schooling is assumed ${ }^{18}$ and the values for $\checkmark$ are assumed to apply also to the 3-year period of compulsory army service from age 18 .

The table shows alternative NPV results, based on different combinations of alternative income growth rates, a higher discount rate, lower value for the m parameters, four years of secondary schooling and zero value for $v$ during army service. Only in some of the yorst assumption cases are the NPVs negative and then only marginally so. 19 We may conclude that terminal vocational schooling in Israel compares favorably with academic schooling, in cost-benefit terms.

\section{Discussion}

This paper has compared, for the case of Israel, vocational secondary schools with academic schools, in terms of their efficacy in enhancing labor market earnings. Using data from the 1983 Census of Population and Housing relating to non post-secondary school attenders, the study shows vocational schooling to be more cost-effective than general academic education. In particular, those vocational school attenders that work in occupations related to course of study pursued at school earn more (by up to 10 percent monthly) than both their peers who studied at academic secondary schools and those who attended vocational schools but found employment in non course-related occupations. These results are highly supportive of recent research on vocational schooling for the United States.

18 Under the 1968 Reform of the Israell educational system, secondary high schools offer a three-year program, compared with four years previously.

19 The NPV "loss" seldom represent more than a few weeks earnings, usually considerably less. 
For example, Campbell, et. al. report earnings gains of 8 percent for US vocational school completers woxking in training-related jobs, over workers who had followed a general high school curriculum; vocational school graduates not working in matched flelds fared no better than those who had studied on general tracks.

Overall, and given the present division of secondary education between academic and vocational schooling, this study has indicated the efficacy of vocational secondary schooling in Israel. This conclusion is buttressed when account is taken of the differing individual background factors that characterize the students attending Israeli academic and vocational secondary schools, respectively.

Most studies of outcomes of vocational and academic schooling do not control explicitly for background differences between the two sub-populations, due to a lack of the requisite data. However, the results of such studies may not be faulted by this omission, because in most developing countries only a small (and highly select) fraction of children attend secondary schools, implying a restricted variance in student samples at the secondary level (Fuller, 1987). In the present case, however, where over 80 per cent of secondary school age teenagers are enrolled in secondary schools, competition for entry into academic schools leads to a process of rationing of academic school places on the basis of student academic abllity: social class and parental background also play a role. Thus vocational secondary school pupils differ from their academic school counterparts in a number of ways, which in turn, affect earnings: they tend to be of lesser academic ability, to come from a lower socio-economic background, are more likely to be of Oriental origin and their parents are 1 ess educationally qualified. Data limitations prevented us from controlling for most of these factors. Yet, in the absence 
of secondary schooling, it is to be expected that these factors would result in a level of earnings for those who attended a vocational school that was lower than that of their academic school peers: attendance at a secondary school results in a closing of this earnings gap between the two groups. In this case, our results understate the true "value added" of vocational schoolIng. 20

We have noted that the present balance of secondary schooling in Israel, between vocational and academic schooling, offers a satisfactory return on societal investment in terminal secondary schooling. However it remains the case that well over half of all those who attended the more costly vocational schools do not work in occupations matching the courses of study pursued at school, nor do the latter benefft from an earnings advantage over their academic school counterparts. Does this suggest that there should be a redistribution of secondary school places in favor of academic schools? This would be so only, and this is doubtful, if it were the case that vocational school students generally were in fact suitable for the more demanding academic secondary education stream.

Our positive conclusions with regard to vocational schooling need to be tempered with a caveat. While vocational schooling overall may be cost effective in comparison with other forms of secondary schooling, it is not so in relation to alternative training modes for youth in the skilled trades. In a recent study, one of the authors compared vocational schools with alternative non-formal training modes in Israel -. notably the traditional

20 However, this argument should not be pressed too far. Unllke the case of vocational schools, most academic high school completers go on to pursue postsecondary study. Since our sample is restricted to academic school attenders who do not continue studying, It relates to the less academically able students at academic schools - a form of negative selection. Yet this group is likely to be closer in background and ability to vocational school attenders generally. 
apprenticeship and factory-based vocational schools (21derman, 1989B). In this context, vocational schools were found not to be cost-effective: they constitute the most expensive skill training mode, without offering any earnings (or productivity) advantage to vocational school attenders over those from alternative training institutions. It was concluded that greater efficiency in the national training effort could be attained by a shift in the training effort away from vocational schooling, in the direction of more closely job-related training modes outside the formal education system. Yet, accounting for only some 7 percent of 15 to 17 year-olds (compared with over 40 percent attending vocational schools), these training institutions are marginal today in Israel, not only in terms of numbers.

The national consensus in Israel on the importance of providing a schooling framework to undertake the role of the social and cultural Integration of Israel's heterogeneous, largely immigrant population acts as a major constraint on the development of those training alternatives that are the norm for youth in other countries. The desire to meet manpower needs for development plays an important role in explaining the growth and size of vocational schooling in Israel (Glasman, 1983). However, a predominant factor was the framework afforded by vocational schools for integrating into the dominant framework of society the large numbers of youth stemming from North Africa, the Middle East and Yemen with Low academic ability and soc10-economic status; by and large the traditional, academic schools were not regarded as providing an approprlate educational framework for most of these immigrant youngsters (Z1derman, 1989A). Thus, vocational secondary schools became the dominant provider of skilled workers for the skilled trades, issues of economic efficiency notwithstanding. Very little is done to develop the 
non-formal job-related training modes as mainstream training institutions; under the aegis of the Ministry of Labor and Social Affairs they concentrate on meeting the needs of disadvantaged and marginal youth. The cost effectiveness of vocational secondary schools in relatio.t to academic ones, then, must be seen against this backcloth, very much in a 'second best' context once the full range of educational and training programs for youth are taken Into account.

The positive findings for vocational schooling presented in this study, supportive of recent research for the United States, 11lustrate the importance of adopting a broader scope than is taken in the typical evaluation study of vocational schooling in Third World countries. Too often such studies, concentrate on earnings and other labor market success Indicators, to the exclusion of the intervening variable relating to the type of occupation followed and its relevance to prior vocational studies. 21 In this paper we have seen that such considerations may be central to a proper understanding of the labor market outcomes of vocational schooling. Future evaluation studies w11l need to pay more attention to issues of curriculum (including the type and scope of vocational studies), as well as to the nature of the occupation followed and its relationship with prior courses of vocational study.

21 There are some notable exceptions, Including an eariy Brazilian case study by de Moura Castro (1975); a forthcoming case study of vocational schools in Hong Kong, also based on Census data and employing a very similar methodology (in terms of matched occupations) to that employed in the present paper. reached positive results for vocational schooling (see Chung, 1990). 


\section{References}

Benavot, A. 1983. "The Rise and Decline of Vocational Bducation." Sociology of Education.

Bishop, J. 1989. "Occupational Training in High School: When Does It Payoff?" Economics of Education Revieu 8(1).

Campbe1l, P.B., K.S. Basinger, M.B. Dauner and M.A. Parks. 1986. Outcomes of Vocational Education for Women. Minorities, the Handicapped and the Poor. Columbus: The National Center for Research in Vocational Education, The Ohio State University.

Campbe11, P.B., J. Elliot, S. Laughlin and E. Seusy. 1987. The Dynamics of Vocational Education Effects on Labor Narket Outcomes. Columbus: The National Center for Research in Vocational Education, The Oh1o State University.

Central Bureau of Statistics, Israel. 1988. "Persons with Vocational Education: Selected Results from the Sample Enumeration." Supplement to Monthly Bulletin of Statistics $39(5)$.

Central Bureau of Statistics, Israel. 1987. Statistical Abstract of Israel, Recent Years. See also, 1987. "National Expenditure on Education 1984/85 and Preliminary Estimates for $1985 / 86$ and for 1986/87." Supplement to Monthly Bulletin of Statistics 38(11).

Chung, Y-P. 1990. "Educated Mis-Employment: Earnings Effects on Being Employed in Un-Matched Fields of Work for Vocational and Technical Education Graduates." Economics of Educatien Reviex 9(4) Forthcoming.

Daymont, T.N. and R. Rumberger. 1982. "The Impace of High School Curriculum on the Earnings and Employability of Youth." In Job Training for Youth, R.E. Taylor, H. Rosen and F.C. Pratzner, eds. Columbus: The National Center for Research in Vocational Education, The Ohio State University.

de Moura Castro, C. 1975. "Academic Education versus Technical Education: Which is More General?" In Educational Altexnatives in Latin America: Social Change and Social stratification. Thomas J. La Bella, ed. Los Angeles, California: UCLA Latin American Center for Publications.

Dougherty, C.R.S, and E. Jimenez. 1987. "The Specification of Earnings Functions: Tests and Implications." Education and Training Discussion Paper Series No. 100. Washington, D.C.: The World Bank.

Foster, P.J. 1965. Education and Social Change in Ghana. London: Routeledge and Kegan Paul.

Fuller, B. 1987. "What School Factors Raise Achievement in The Third World?" Review of Educational Research 57(3). 
Glasman, N.S. 1983. "Israel: Political Roots and Effects of Two Educational Declaions." In Rolitics and Bducation' Cases from Eleven Countrtes, ed. R. Murray Thomas, 191-210. Oxford: Pergamon Press.

Grootaert, C. 1988. Cote d'Ivolre's Vocational and Technical Education. PPR Working Paper No. 19. Washington, D.C: The World Bank.

Halvorsen, R, and R. Palmquist. 1980. "The Interpretation of Durmy Variables in Semilogarithmic Equations." American Economic Review 70(3).

Hotchkiss, L. 1989. Training. Training-Related Occupation and Weges: Implications for Theory and Policy. Washington, D.C.: Decision Resources Corporation.

Iram, Y. and C. Balicki. 1980. "Vocational Education In Switzerland and Israel: A Comparative Analysis." Canadian and International Education 9(1).

Meyer, R. 1981. An Economic Analysis of High School Vocational Education. Washington, D.C.: The Urban Institute.

Moock, P.R, and R.T. Bellew. 1988. Vocational and Technical Education in Peru, PPR Working Paper No. 87. Washington, D.C.: The World Bank.

Neuman, S. and A. Ziderman. 1989. "Vocational Schools Can Be More Cost Effective Than Academic Schools: An Israeli Case Study." Comparative Education 25(2).

Psacharopoulos, G. 1987. "To Vocationalise or Not to Vocationalise: That Is the Curriculum Question." International Review of Education. $33(2)$.

Tilak, J.B.G. 1988. "Economics of Vocationalization: A Review of the Evidence." Canadian and International Education 17(1).

Tsang, M. 1989. The Costs of Vocational Training, Washington, D.C.: The World Bank, Mimeo.

United States Department of Education: National Assessment of Vocational Education, 1989. Einal Report: Summary of Findings and Recommendations. Washington, D.C.: United States Department of Education.

Ziderman, A. 1989A. "Focus on Secondary Schooling in Israel." Comparative Education Review $33(2)$.

Z1derman, A. 1989B. "Alternative Training Modes for Youth in Israel: Results from Longitudinal Data." Comparative Education Review $33(2)$.

Zymelman, M. 1976. The Economic Evaluation of Vocational Training Brograms. Baltimore: The John Hopkins University Press. 
Ioble 1

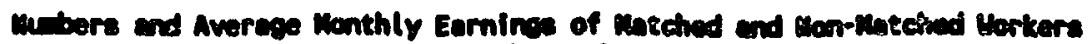
by subject of stuch

Fult Time Male Solaried Horkers, Attendere of Vecationl schools - Iereall census, 19us

\begin{tabular}{|c|c|c|c|c|c|c|c|c|}
\hline \multirow[b]{2}{*}{$\begin{array}{l}\text { Ares } \\
\text { of } \\
\text { Study }\end{array}$} & \multicolumn{2}{|c|}{$\begin{array}{l}\text { All Vocational } \\
\text { School Attenders }\end{array}$} & \multicolumn{3}{|c|}{$\begin{array}{c}\text { Direct } \\
\text { Iraining-Occugetion Matchings }\end{array}$} & \multicolumn{3}{|c|}{$\begin{array}{c}\text { Hider } \\
\text { Irainino-ocelogt ion Hatchings }\end{array}$} \\
\hline & $\begin{array}{l}\text { Number } \\
\text { of } \\
\text { Workers }\end{array}$ & $\begin{array}{l}\text { Average } \\
\text { Monthly } \\
\text { Earnings" }\end{array}$ & $\begin{array}{c}\text { Percent } \\
\text { Monthly } \\
\text { Workers } \\
\text { in } \\
\text { Matched } \\
\text { Occupstions }\end{array}$ & $\begin{array}{l}\text { Average } \\
\text { of } \\
\text { Earnings } \\
\text { of } \\
\text { Matched. } \\
\text { Workers }\end{array}$ & $\begin{array}{l}\text { Average } \\
\text { Monthiy } \\
\text { Earnings } \\
\text { of } \\
\text { Won-Matchyd } \\
\text { Workers }\end{array}$ & $\begin{array}{c}\text { Percent } \\
\text { Monehly } \\
\text { Workers } \\
\text { in } \\
\text { Matched } \\
\text { Occupetiens }\end{array}$ & $\begin{array}{l}\text { Average } \\
\text { of } \\
\text { Eornings } \\
\text { of } \\
\text { Motched } \\
\text { Horkers }\end{array}$ & $\begin{array}{l}\text { Average } \\
\text { Nonthly } \\
\text { Earnings } \\
\text { of } \\
\text { Mon-Natched } \\
\text { Morkers }\end{array}$ \\
\hline Agriculture & 1,002 & $\begin{array}{c}37,898 \\
(28,782)\end{array}$ & $\begin{array}{l}6.09 \\
(61)\end{array}$ & $\begin{array}{l}29,324 \\
(11,861)\end{array}$ & $\begin{array}{l}38,448 \\
(29,453)\end{array}$ & $\begin{array}{l}14.47 \\
(145)\end{array}$ & $\begin{array}{r}45,849 \\
(28,814)\end{array}$ & $\begin{array}{c}36,571 \\
(28,408)\end{array}$ \\
\hline Electriciey & 1,357 & $\begin{array}{c}37,602 \\
(27,694)\end{array}$ & $\begin{array}{l}42.08 \\
(571)\end{array}$ & $\begin{array}{l}37,768 \\
(18,918)\end{array}$ & $\begin{array}{c}37,482 \\
(32,639)\end{array}$ & $\begin{array}{l}51.14 \\
(694)\end{array}$ & $\begin{array}{c}41,217 \\
(34,151)\end{array}$ & $\begin{array}{l}33,824 \\
(17,694)\end{array}$ \\
\hline Electronics & 691 & $\begin{array}{c}43.759 \\
(29,633)\end{array}$ & $\begin{array}{l}49.06 \\
(339)\end{array}$ & $\begin{array}{l}51.215 \\
(35.915)\end{array}$ & $\begin{array}{l}36,579 \\
(19,461)\end{array}$ & $\begin{array}{l}60,35 \\
(417)\end{array}$ & $\begin{array}{c}50,212 \\
(34,162)\end{array}$ & $\begin{array}{c}33,938 \\
(16,814)\end{array}$ \\
\hline Metal work & 4,337 & $\begin{array}{c}36,834 \\
(28,530)\end{array}$ & $\begin{array}{r}37.91 \\
(1644)\end{array}$ & $\begin{array}{l}36,944 \\
(26,525)\end{array}$ & $\begin{array}{c}36,767 \\
(29,693)\end{array}$ & $\begin{array}{r}45.35 \\
(1967)\end{array}$ & $\begin{array}{l}39.996 \\
(37,134)\end{array}$ & $\begin{array}{c}34,210 \\
(18,170)\end{array}$ \\
\hline Automechanics & 1,967 & $\begin{array}{c}36,341 \\
(22,450)\end{array}$ & $\begin{array}{l}42.76 \\
(841)\end{array}$ & $\begin{array}{l}37,122 \\
(23,655)\end{array}$ & $\begin{array}{r}35,757 \\
(21,497)\end{array}$ & $\begin{array}{l}56.58 \\
(1113)\end{array}$ & $\begin{array}{r}38,556 \\
(25,517)\end{array}$ & $\begin{array}{c}33,451 \\
(17,258)\end{array}$ \\
\hline $\begin{array}{l}\text { Bookkeeping, } \\
\text { Secretarial \& clerical }\end{array}$ & 331 & $\begin{array}{c}38,007 \\
(22,045)\end{array}$ & $\begin{array}{l}51.06 \\
(169)\end{array}$ & $\begin{array}{c}37.990 \\
(19.139)\end{array}$ & $\begin{array}{c}38,025 \\
(26,777)\end{array}$ & $\begin{array}{l}58.31 \\
(193)\end{array}$ & $\begin{array}{c}40,945 \\
(22,257)\end{array}$ & $\begin{array}{c}33,899 \\
(21,148)\end{array}$ \\
\hline Sewing \& fashion & 20 & $\begin{array}{c}30,213 \\
(16,522)\end{array}$ & $\begin{array}{c}20.00 \\
(4)\end{array}$ & $\begin{array}{l}17,827 \\
(3,175)\end{array}$ & $\begin{array}{c}33,516 \\
(17,126)\end{array}$ & $\begin{array}{c}20.00 \\
(4)\end{array}$ & $\begin{array}{l}17,827 \\
(3,175)\end{array}$ & $\begin{array}{c}33,516 \\
(17,126)\end{array}$ \\
\hline Hotel Management & 93 & $\begin{array}{c}29,433 \\
(10,893)\end{array}$ & $\begin{array}{l}40.86 \\
(38)\end{array}$ & $\begin{array}{c}31,009 \\
(10,112)\end{array}$ & $\begin{array}{c}28,364 \\
(11,364)\end{array}$ & $\begin{array}{r}40.86 \\
(38)\end{array}$ & $\begin{array}{c}31,009 \\
(10,112)\end{array}$ & $\begin{array}{c}28,344 \\
(11,364)\end{array}$ \\
\hline Total & 9,798 & $\begin{array}{c}37,396 \\
(27,129)\end{array}$ & $\begin{array}{c}37.4 \\
(3667)\end{array}$ & $\begin{array}{c}38,274 \\
(25,638)\end{array}$ & $\begin{array}{c}36,870 \\
(27,973)\end{array}$ & $\begin{array}{c}46.7 \\
(4571)\end{array}$ & $\begin{array}{c}40,892 \\
(33,904)\end{array}$ & $\begin{array}{c}34,338 \\
(20,037)\end{array}$ \\
\hline
\end{tabular}

- Standard deviotions in parentheses

- absolute numbers in parentheses 
Ioble?

Regreasion of Monthly Earnirien (In)

Full Time, Male, salaried Vorkers, Attendors of Vocational schools

Iereolf centu, 1905

$\log 79$

\begin{tabular}{|c|c|c|c|c|}
\hline \multirow{2}{*}{$\begin{array}{l}\text { Independent } \\
\text { Variables }\end{array}$} & \multicolumn{2}{|c|}{ Direct Matchings } & \multicolumn{2}{|c|}{ Hider Matchings } \\
\hline & Coefficient & t-statistic & coefficient & $t-$ Statistic \\
\hline $\begin{array}{l}\text { YRS.SCH } \\
\text { EXP } \\
\text { EXP } \\
\text { EXPP-ins.SCH }\end{array}$ & $\begin{array}{c}0.024 \\
0.025 \\
-0.0007 \\
0.002\end{array}$ & $\begin{array}{l}1.51 \\
2.13 \\
5.07 \\
2.37\end{array}$ & $\begin{array}{c}0.022 \\
0.025 \\
-0.0007 \\
0.002\end{array}$ & $\begin{array}{l}1.38 \\
2.06 \\
4.98 \\
2.36\end{array}$ \\
\hline $\begin{array}{l}\text { Certificatio } \\
\text { P.CERT } \\
\text { S.CERT } \\
\text { BAG } \\
\text { WEEKS (ln) } \\
\text { HOURS (ln) } \\
\text { ETHNIC }\end{array}$ & $\begin{array}{r}0.011 \\
0.073 \\
0.112 \\
0.302 \\
0.374 \\
-0.137\end{array}$ & $\begin{array}{r}0.44 \\
3.10 \\
3.46 \\
13.16 \\
9.66 \\
11.84\end{array}$ & $\begin{array}{c}0.013 \\
0.067 \\
0.103 \\
0.298 \\
0.367 \\
-0.134\end{array}$ & $\begin{array}{r}0.38 \\
2.84 \\
3.23 \\
13.05 \\
0.53 \\
11.66\end{array}$ \\
\hline $\begin{array}{l}\text { Economic Sec } \\
\text { IND } \\
\text { ELECT } \\
\text { COMM } \\
\text { FIN } \\
\text { TRANS } \\
\text { PUB } \\
\text { PRIV } \\
\text { CONST }\end{array}$ & $\begin{array}{c}0.101 \\
0.284 \\
0.11 \\
0.133 \\
0.084 \\
0.019 \\
-0.047 \\
-0.005\end{array}$ & $\begin{array}{l}3.08 \\
6.48 \\
0.30 \\
3.31 \\
2.36 \\
0.55 \\
1.16 \\
0.14\end{array}$ & $\begin{array}{l}0.095 \\
0.285 \\
0.004 \\
0.134 \\
0.092 \\
0.033 \\
-0.054 \\
0.00002\end{array}$ & $\begin{array}{l}2.90 \\
6.54 \\
0.23 \\
3.49 \\
2.58 \\
0.95 \\
1.34 \\
0.00\end{array}$ \\
\hline $\begin{array}{l}\text { Subject of S } \\
\text { ELECTRIC } \\
\text { ELECTRON } \\
\text { METAL } \\
\text { AUTO } \\
\text { CLERIC } \\
\text { SEH } \\
\text { HOTEL } \\
\text { VOC.M. }\end{array}$ & $\begin{array}{c}0.055 \\
0.184 \\
0.057 \\
0.042 \\
0.046 \\
-0.053 \\
-0.024 \\
0.055\end{array}$ & $\begin{array}{l}2.36 \\
6.62 \\
2.88 \\
3.27 \\
1.25 \\
0.42 \\
0.41 \\
4.54\end{array}$ & $\begin{array}{c}0.033 \\
0.158 \\
0.040 \\
0.043 \\
0.016 \\
-0.054 \\
-0.038 \\
0.194\end{array}$ & $\begin{array}{l}1.43 \\
5.67 \\
2.01 \\
1.97 \\
0.46 \\
0.43 \\
0.65 \\
9.80\end{array}$ \\
\hline Intercept & 6.771 & 25.72 & 6.838 & 26.07 \\
\hline$R^{2}$ & 0.155 & & 0.161 & \\
\hline
\end{tabular}




\section{Irble 3}

Regreasion of Monthly Eaming CIns

Full Tive, Male, Salaried Workers Cenoral and Vocational school Attenders Iarcell consur. 19as

n=i3ars

\begin{tabular}{|c|c|c|c|c|c|c|}
\hline \multirow{2}{*}{$\begin{array}{l}\text { Independent } \\
\text { Variables }\end{array}$} & \multicolumn{2}{|c|}{ Non-Matched Regression } & \multicolumn{2}{|c|}{ Direct Matchin 98} & \multicolumn{2}{|c|}{ Mider Matchings } \\
\hline & Coefficient & i-Statlstic & Coefficient & t-Statistic & Coefficient & t-Statistic \\
\hline $\begin{array}{l}\text { YRS.SCH } \\
\text { EXP } \\
\text { EXP2 } \\
\text { EXPAYRS.SCH } \\
\text { WEEKS (In) } \\
\text { HOURS (In) } \\
\text { ETHNIC }\end{array}$ & $\begin{array}{c}0.020 \\
0.036 \\
-0.0008 \\
0.001 \\
0.314 \\
0.301 \\
-0.130\end{array}$ & $\begin{array}{r}1.33 \\
3.69 \\
7.40 \\
1.62 \\
16.66 \\
9.25 \\
13.49\end{array}$ & $\begin{array}{c}0.017 \\
0.034 \\
-0.0008 \\
0.001 \\
0.312 \\
0.312 \\
-0.131\end{array}$ & $\begin{array}{r}1.34 \\
3.52 \\
7.32 \\
1.79 \\
16.58 \\
9.60 \\
13.59\end{array}$ & $\begin{array}{c}0.017 \\
0.034 \\
-0.0008 \\
0.001 \\
0.312 \\
0.313 \\
-0.129\end{array}$ & $\begin{array}{r}1.29 \\
3.49 \\
7.31 \\
1.82 \\
16.57 \\
9.64 \\
13.43\end{array}$ \\
\hline $\begin{array}{l}\text { Economic Se } \\
\text { IND } \\
\text { ELECT } \\
\text { CONM } \\
\text { FIN } \\
\text { TRAMS } \\
\text { PUB } \\
\text { PRIV } \\
\text { COUST }\end{array}$ & $\begin{array}{r}0.075 \\
0.267 \\
-0.026 \\
0.131 \\
0.072 \\
-0.029 \\
-0.055 \\
-0.003\end{array}$ & $\begin{array}{l}2.51 \\
6.73 \\
0.82 \\
3.88 \\
2.26 \\
0.92 \\
1.53 \\
0.08\end{array}$ & $\begin{array}{r}0.072 \\
0.260 \\
-0.028 \\
0.128 \\
0.073 \\
-0.029 \\
-0.072 \\
0.006\end{array}$ & $\begin{array}{l}2.60 \\
6.55 \\
0.86 \\
3.82 \\
2.29 \\
0.94 \\
1.99 \\
0.13\end{array}$ & $\begin{array}{r}0.069 \\
0.261 \\
-0.027 \\
0.130 \\
0.076 \\
-0.026 \\
-0.017 \\
0.003\end{array}$ & $\begin{array}{l}2.30 \\
6.59 \\
0.84 \\
3.88 \\
2.32 \\
0.83 \\
1.96 \\
0.08\end{array}$ \\
\hline $\begin{array}{l}\text { Occupation: } \\
\text { ACAD } \\
\text { TECH } \\
\text { MUNAG } \\
\text { CLER } \\
\text { SALES } \\
\text { SERY } \\
\text { UNSKILL } \\
\text { SKILL }\end{array}$ & $\begin{array}{l}0.253 \\
0.369 \\
0.496 \\
0.194 \\
0.195 \\
0.186 \\
0.102 \\
0.180\end{array}$ & $\begin{array}{l}3.30 \\
8.18 \\
1.03 \\
4.43 \\
4.22 \\
4.04 \\
1.98 \\
4.20\end{array}$ & $\begin{array}{l}0.283 \\
0.360 \\
0.525 \\
0.215 \\
0.224 \\
0.212 \\
0.134 \\
0.173\end{array}$ & $\begin{array}{r}3.70 \\
7.99 \\
11.65 \\
4.90 \\
4.87 \\
4.60 \\
2.60 \\
4.03\end{array}$ & $\begin{array}{l}0.279 \\
0.361 \\
0.480 \\
0.211 \\
0.199 \\
0.208 \\
0.134 \\
0.174\end{array}$ & $\begin{array}{r}3.65 \\
8.01 \\
10.68 \\
4.82 \\
4.35 \\
4.53 \\
2.61 \\
4.07\end{array}$ \\
\hline $\begin{array}{l}\text { Certificati } \\
\text { P.CERT } \\
\text { S.CERT } \\
\text { BAG }\end{array}$ & $\begin{array}{l}0.0005 \\
0.071 \\
0.122\end{array}$ & $\begin{array}{l}0.02 \\
3.55 \\
5.01\end{array}$ & $\begin{array}{r}-0.001 \\
0.063 \\
0.113\end{array}$ & $\begin{array}{l}0.07 \\
3.18 \\
4.66\end{array}$ & $\begin{array}{r}-0.001 \\
0.064 \\
0.116\end{array}$ & $\begin{array}{l}0.05 \\
3.22 \\
6.81\end{array}$ \\
\hline $\begin{array}{l}\text { vor } \\
\text { voc.n } \\
\text { voc.u }\end{array}$ & $\begin{array}{c}0.026 \\
\ldots \\
\ldots\end{array}$ & $\begin{array}{c}2.42 \\
\ldots \\
\ldots\end{array}$ & $\begin{array}{c}-0 \\
0.0 \% 6 \\
-0.003\end{array}$ & $\begin{array}{l}-- \\
6.84 \\
0.27\end{array}$ & $\begin{array}{l}0.081 \\
0.013\end{array}$ & $\begin{array}{l}\cdots \\
6.27 \\
1.05\end{array}$ \\
\hline Intercept & 6.969 & 31.66 & 6.940 & 31.49 & 6.959 & 31.57 \\
\hline$R^{2}$ & 0.169 & $\ldots$ & 0.173 & $\cdots$ & 0.173 & -- \\
\hline
\end{tabular}


Iebles

Increantel wot Precent value of

Vocational school ine over Acadeafe Secondery School ino

(Iereelf stakel, per student)

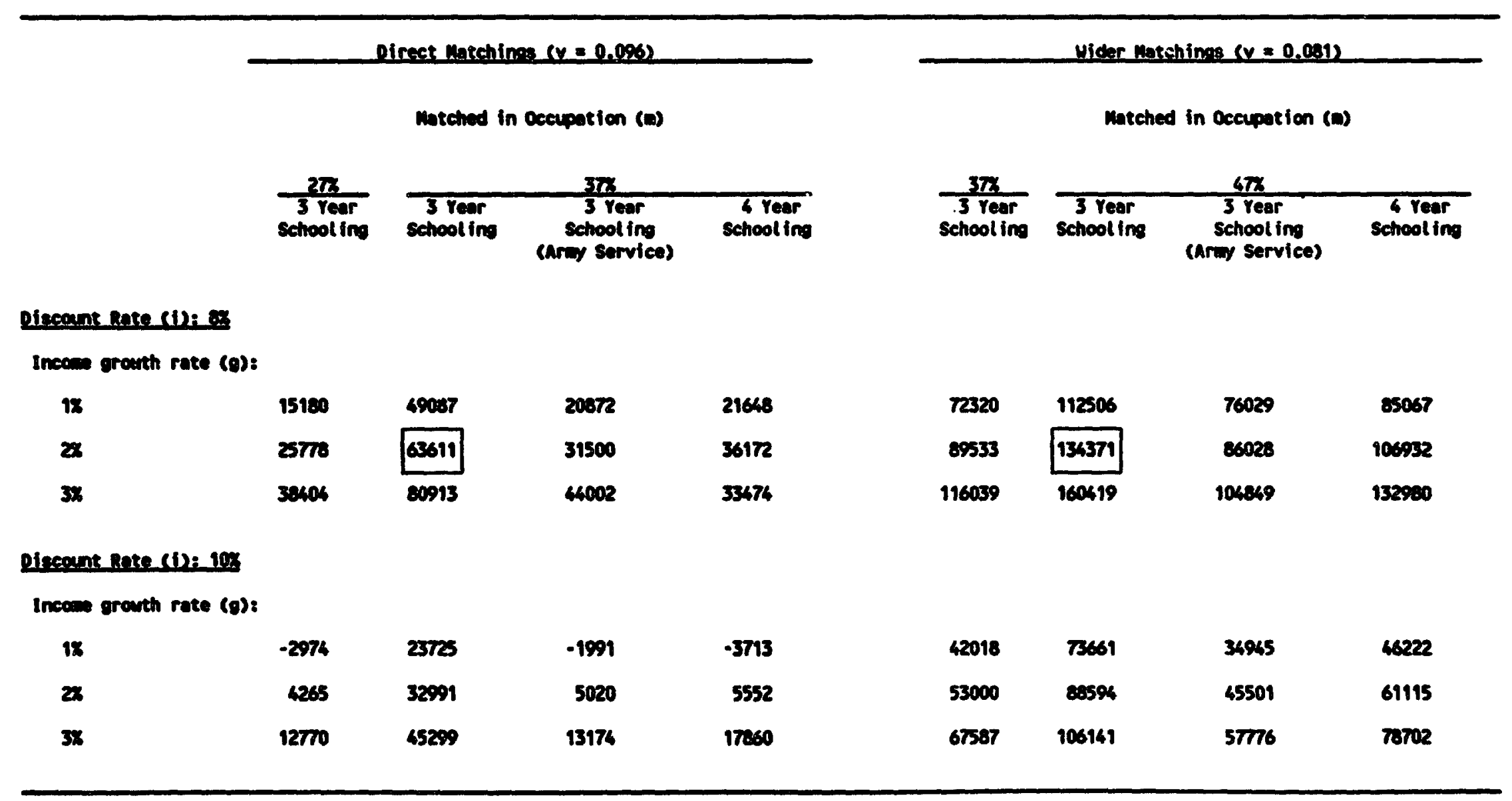




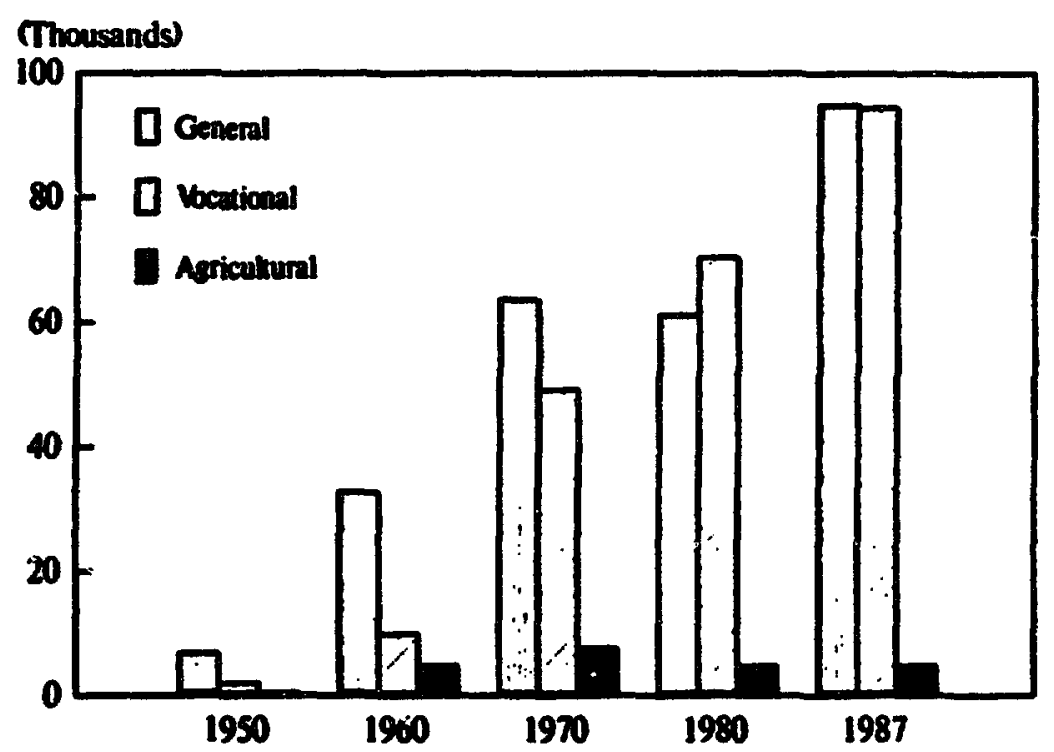

Figure 1

Number of Siudents in Secondary Schools (Hebrew Estreation)

bonatsas 
motching of Voctional Education cource with occupotion

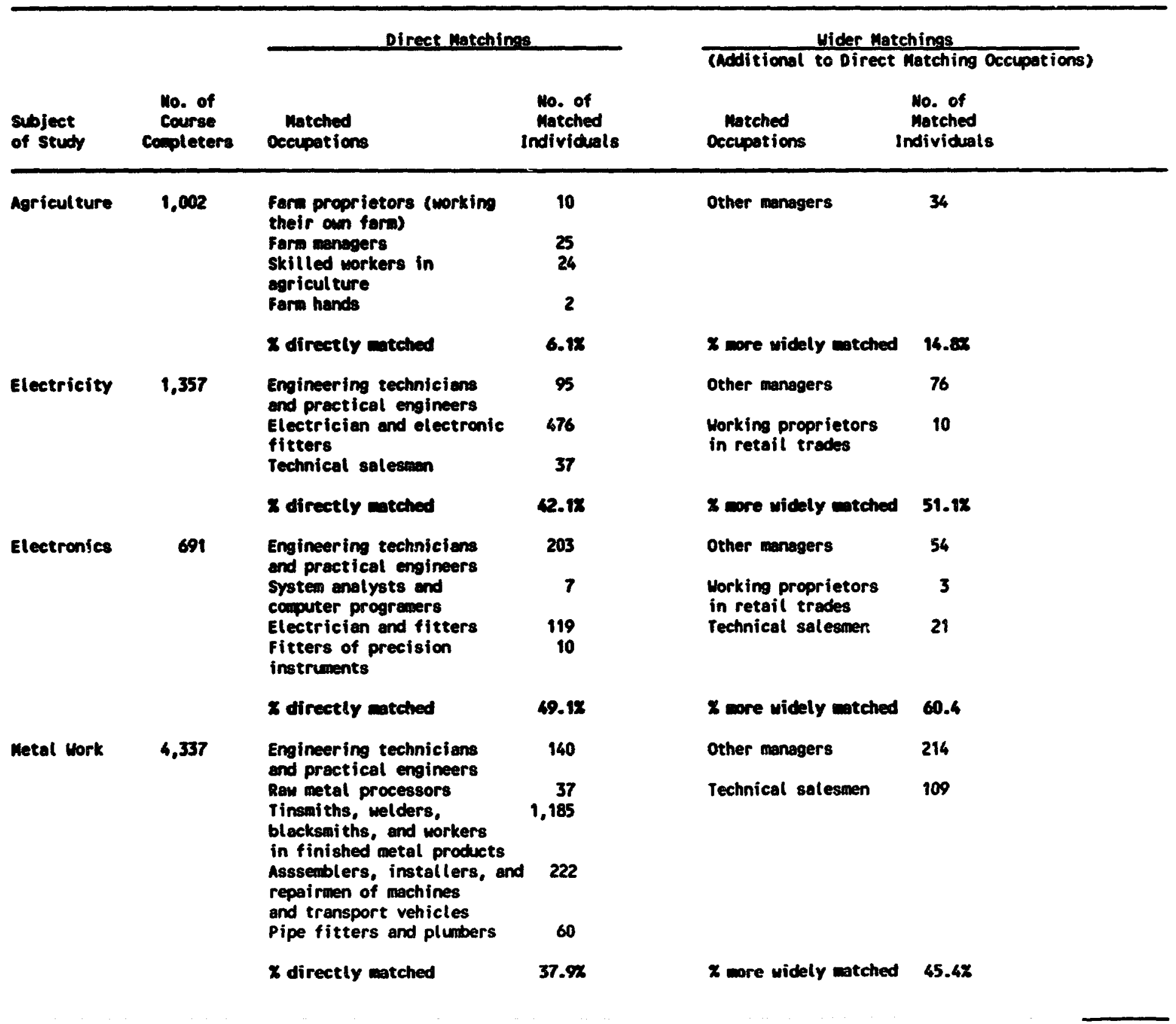


APPEDDIX

Matching of Voctional Education Course with Occupotion

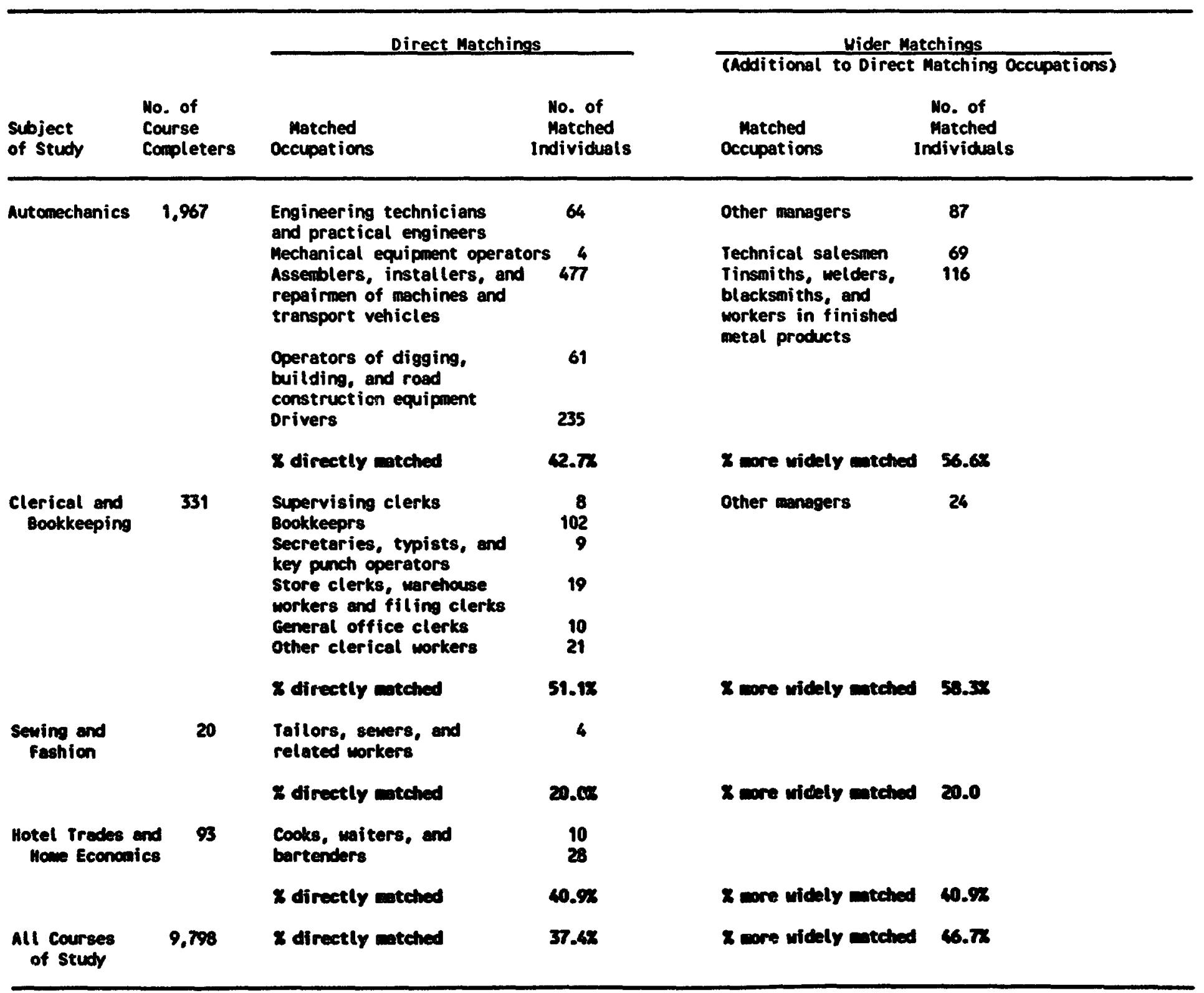


Intle

WPS662 Trends in Social Indicators and
Social Sector Financing

WPS663 Bank Holding Companies: A Better Structure for Conducting Universal Banking?

WPS664 Should Employee Participation Be Part of Privatization?

WPS665 Microeconomic Distortions: Static Losses and their Effect on the Efficiency of Investment

WPS666 Agriculture and the Transition to the Market
WPS667 VERs Under Imperfect Competition and Foreign Direct investment:

A Case Study of the U.S.-Japan Auto VER

WPS668 Inflation Tax and Deficit Financing in Egypt

WPS669" Are High Real interest Rates Bad for World Economic Growth

WPS670 Inflation Adjusțments of Financial Statements: Application of International Accounting Ştandard 29

WPS671 Lessons from the Heterodox Stabilization Programs

WPS672 The Macroaconomics of Public: Sector Deficits: The Case of Ghana

WPS673 The Macroeconomics of Public Sector Deficits: The Case of Pakistan

WPS674 Distributional Effects of Adjustment Policies: Simulations for Two Archetype Economies
Author

Jacques van der Gaag

Elene Makonnen

Pierre Englebert

Samuel H. Talley

Barbara W. Lee

Ramón López

Karen M. Brooks Jos6 Luis Guasch

Avishay Braverman

Csaba Csaki

Date

Contact

forpaper

May 1991

B. Rosa 33751

May 1991

Z. Seguis 37665

May 1991

G. Örraca-Tott 37646

May 1991

WDR Office 31393

May 1991

C. Spooner 30464

Jaime de Melo

David Tarr

Hinh T. Dinh
Marcelo Giugale

May 1991

L. Santano 80553

Nemat Shafik

Jalaleddin Jalali

May 1991

M. Divino

33739

Yaaqov Goldschmidt

Jacob Yaron

May 1991

C. Spooner 30464

May 1991

E. Khine 39361

Nissan Liviatan

May 1991

R. Luz

Roumeon folam

Deborah L. Wetzel

34303

Naderm U. Haque

Peter Montiel

May 1991

R. Luz

34303

Francois Bourguignon

May 1991

WDR Office 31393 
PRE Workina Paper Series

Inte

WPS675

Are Buybacks Back? Menu-Driven

Debt-Reduction Schemes with

Heterogenous Creditors

WPS676 Higher Education in the Republic

of Yemen: The University of Sana'a

WPS677 On Economic Transformation in East- Andres Solimano

Central Europe: A Historical and

International Perspective

WPS678 Economic Growth: A Review of the Theoretical and Empirical Literature

WPS679 Poverty Alleviation in Mexico

WPS680 On Hunger and Public Action

-

WPS681 Political-Economy Arguments for UniformTariff

WPS682 Intertemporal Substitution, Risk Aversion, and Private Savings in Mexico

WPS683 Vocational Schooling, Occupational Shoshana Neuman Matching, and Labor Market Earnings Adrian Ziderman in Israol
Author

Ishac Diwan

Mark M. Spiegel

Viswanathan Selvaratnam

Omporn L. Regel

David Renelt

Santiago Lovy

Martin Ravallion

Arvind Panagariya

Dani Rodrik

oPatricio Arrau

Swoder van Wijnbergen
Date

May 1991

May 1991

May 1991

May 1991

May 1991

May 1991

May 1991

May 1991 .

May 1991
Contact

forpaper

S. King-Watson

33730

C. Cristobal

33640

E. Khine

39361

R. Luz

34303

M. Stroude

38831

C. Spooner 30464

K. Cabana

37947

S. King-Watson 31047

C. Cristobal 33640 